\title{
Bacillus cereus group: genetic aspects related to food safety and dairy processing
}

\author{
Grupo do Bacillus cereus: aspectos genéticos relacionados \\ à segurança alimentar e ao processamento de derivados lácteos
}

\section{Gabriel Augusto Marques Rossi ${ }^{1 *}$, Carlos Eduardo Gamero Aguilar ${ }^{1}$, Higor Oliveira Silva ${ }^{1}$, Ana Maria Centola Vidal ${ }^{2}$}

\begin{abstract}
Bacillus cereus group includes not pathogenic and high pathogenic species. They are considered as a risk to public health due to foodborne diseases and as an important cause of economic losses to industries due to production of spoilage enzymes. Some researches have been performed in order to assess the possible factors that contribute to put public health into risk because of consumption of food contaminated with viable cells or toxins which have complex mechanisms of production. The control of these bacteria in food is difficult because they are resistant to several processes used in industries. Thus, in this way, this review focused on highlighting the risk due to toxins production by bacteria from $B$. cereus group in food and the consequences for food safety and dairy industries.
\end{abstract}

KEYWORDS: biofilm; genome; milk; microbiology; toxins.
RESUMO: Diversas espécies fazem parte do grupo de Bacillus cereus, desde algumas apatogênicas até outras com alta patogenicidade. Consistem em risco à saúde pública decorrentes de toxinfecções alimentares, além de causarem importantes perdas econômicas para as indústrias em virtude da produçáo de enzimas deteriorantes. O controle da contaminação em alimentos por esses micro-organismos é difícil, visto que são resistentes a vários tratamentos utilizados pelas indústrias. Assim, diante do exposto, esta revisão objetivou fornecer informações em relação aos aspectos genéticos desse grupo de bactérias e seus mecanismos de produção de toxinas, além de ressaltar a importância e as novas estratégias de controle para as companhias alimentícias e de laticínios.

PALAVRAS-CHAVE: biofilmes; genoma; leite; microbiologia; toxinas.

'Faculdade de Ciências Agrárias e Veterinárias, Universidade Estadual Paulista “Júlio de Mesquita Filho" - Jaboticabal (SP), Brazil ${ }^{2}$ Faculdade de Zootecnia e Engenharia de Alimentos, Universidade de São Paulo - Pirassununga (SP), Brazil 


\section{REVIEW}

The Bacillus cereus group is composed by several species that are able to put the public health into risk due to production of toxins. These bacteria also cause economic losses to food industries (including dairy), and new strategies for their control have been suggested recently. In this way, this review brings information regarding the genetic aspects of this bacterial group and their complex mechanisms for toxins production, and highlights the importance of the control on food industries and dairy and recent strategies for control.

The $B$. cereus group aggregates eight distinct species, as follow: B. cereus sensu stricto (s.s.), Bacillus thuringiensis, Bacillus mycoides, Bacillus pseudomycoides, Bacillus anthracis, Bacillus weihenstephanensis, Bacilluscytotoxicus (GUINEBRETIÈRE et al., 2013) and Bacillus toyonensis (JIMÉNEZ et al., 2013). Furthermore, the inclusion of other four species in this group has been proposed: Bacillus wiedmannii sp. Nov. (MILLER et al., 2016), Bacillus bingmayongensis sp. nov. (LIU et al., 2014), Bacillus manliponensis sp. nov. (JUNG et al., 2011) and Bacillus gaemokensis sp. nov. (JUNG et al., 2010).

These bacteria have high similarity among their genomes. However, they present different phenotypic characteristics that are mainly explained due to transfer of genes through plasmids (PATIÑO-NAVARRETE; SANCHIS, 2016). They are rod-shaped, Gram-positive, facultative anaerobe and spore producers, which allows their survival on heat-treated food. Between the bacteria included in this group, B. cereus sensu stricto (s.s.) is highlighted because of its capacity to cause foodborne diseases (FDA, 2012).

The $B$. anthracis is also highlighted in this group out of its ability to cause a disease characterized by lesions on skin, respiratory or digestive tracts, which can be fatal. Some strains of $B$. cereus sensu stricto (s.s.) carries plasmids similar to those of $B$. anthracis and are considered as able to cause an anthrax-like disease (MARSTON et al., 2016). This virulence is exchanged among strains through plasmids $\mathrm{PBCXO} 1$ and pBC210 (SCARFF et al., 2016). Some B. cereus sensu stricto (s.s.) strains are considered as emerging and able to cause a persistent bacteremia (SCHAEFER et al., 2016) or brain abscess and meningoencephalitis (TUSGUL et al., 2016).

The bacteria included in B. cereus group can be differentiated on their phonotypical aspects (SCHLEIFER; WHITMAN, 2009). However, the molecular differentiation between the species from this group is complex. HELGASON et al. (2000) showed high genetic similarity on strains of $B$. cereus sensu stricto (s.s.), B. thuringiensis and B. anthracis, and emphasized that phenotypically differences maybe occur due to transfer of virulence factors through plasmids.

Molecular methods have been used in order to differentiate these bacilli (CAAMAÑO-ANTELO et al., 2015), mainly using phylogenetic trees which are able to form groups of strains according to their genomic characteristics and the potential risk to public health, among other phenotypically characteristics (LIU et al., 2015; KOVAC et al., 2016). KOVAC et al. (2016) proposed the use of a phylogenetic classification of these bacteria instead of taxonomic classification to evaluate the risk of diarrheal syndrome. These authors established higher risk for toxins production on groups formed by distinct species on some phylogenetic groups.

The importance of B. cereus sensu stricto (s.s.) for food safety is known from a long time. This bacterium was considered as responsible by $19 \%$ of the foodborne outbreaks reported in the Unites States from 1998 to 2008 (BENNETT et al., 2013). This bacterium is able to survival to some thermal processes due to its ability to produce spores, which the germination and multiplication are influenced by $\mathrm{pH}$, food composition and thermal treatments (WARDA et al., 2015). The heat treatments can damage spores, but they are able to be repaired using a process in which the $\mathrm{CdnL}$ gene is involved and posteriorly multiply (WARDA et al., 2016).

This bacterium is able to cause two syndromes: the emetic, due to a heat resistant toxin (cereulide) that is produced on food; and the diarrheic, which occurs through consumption of a high quantity of spores or cells on food which produce diarrheic toxins (FDA, 2012). The diarrheic syndrome is characterized by the occurrence of diarrhea, cramps and vomiting, which begins after 6 to 15 hours after food consumption. The emetic syndrome is characterized by vomiting occurrence, but diarrhea can also occur, and the symptoms are observed after 30 minutes up to 6 hours after the ingestion of food contaminated with toxins. One strain of this bacterium is able to cause both syndromes (OH et al., 2012). Furthermore, other species included in this bacterial group are considered as able to produce toxins, highlighting the complexity related to the risk for public health (KOVAC et al., 2016).

The production of diarrheal toxins occurs during bacterial multiplication on intestines, and at least three toxins are involved on occurrence of diarrheal syndrome: hemolysin BL (HBL), nonhemolytic enterotoxin (Nhe) and cytotoxin $\mathrm{k}(\mathrm{CytK})$. Besides, the genes hblA, hblC, hblD, nheA, nheB, nheC, cytK1 and cytK2 are involved on their production (EHLING-SCHULZ et al., 2004). The transcription of hblA, hblC, hblD, nheA, nheB, nheC genes is related to a regulator pleiotropic regulator of extracelular virulence (PlcR) (LINDBÄCK et al., 2004; GOHAR et al., 2008). In addition, the flagellar protein FlhF is essential to the complete virulence, probably through the influence on production and secretion of proteins (MAZZANTINI et al., 2016), and also the capacity of intestinal mucous to retain bacterial cells and possibly to protect enterotoxins from intestinal degradation (TSILIA et al., 2016).

JEßBERGER et al. (2015) concluded that the production of Nhe and HBL toxins was more complex than expected, possibly involving factors such as transcriptional proteins, post-transcriptional and post-translational mechanisms and environmental factors. 
The occurrence of emetic syndrome is related to the action of a pre-formed toxin (cereulide) during bacterial sporulation on food (MCKILLIP, 2000), codified by ces gene. This toxin is heat-stable and resistant to low $\mathrm{pH}$ values. The gene is located on a plasmid similar to pXO1 of $B$. anthracis (LÜCKING et al., 2015). The capacity of $B$. weihenstephanensis strains to produce cereulide has been proven (THORSEN et al., 2006). The detection of the highest concentration of this toxin occurs during the beginning of the stationary phase of bacterial multiplication, and it is probably linked to a specific linage of these bacteria (EHLING-SCHULZ et al., 2005). These bacteria are able to produce at least 18 structures homologous to cereulide, and seven are known as Isocereulides (A-G) and recognized as cytotoxic. The isocereulides $\mathrm{A}$ and $\mathrm{C}$ show the highest and lowest cytotoxic action, respectively (MARXEN et al., 2015).

KRANZLER et al. (2016) have proven that cereulide production depends on temperature. These authors highlighted that the risk for emetic syndrome cannot be established using the counting of microorganisms or multiplication, because the toxin production was interrupted on temperatures that allow the highest bacterial multiplication and Isocereulide A (the most cytotoxic) production was higher on low temperatures.

Agreeing with their results, DOMMEL et al. (2011) have shown that cereulide production was inhibited during bacterial multiplication on distinct concentrations of sodium chloride $(\mathrm{NaCl})$. These authors concluded that cereulide production is complex and depends on intrinsic and extrinsic factors, and the risk of emetic syndrome cannot be established through counting viable bacterial cells on food.

Although the mechanisms of toxins production are not fully understood, their effects have been known from a long time. SCHMID et al. (2016) investigated three foodborne outbreaks using epidemiological methods and concluded that the food involved were potatoes, fruit salad, deer meat ragout and pears/cranberries. Furthermore, these authors found genetic similarity among an isolate obtained from a patient with others from strawberry butter and spinach cream using molecular methods, showing the importance of the use of distinct methodologies to investigate outbreaks.

ZHOU et al. (2014) reported another foodborne outbreak due to consumption of fermented black beans (Douchi) and showed the capacity of the strain to produce cereulide on temperatures higher than $37^{\circ} \mathrm{C}$, probably allowing toxin production on intestine and food. Although the illness caused by this bacterium is usually mild, sometimes it can cause death. DIERICK et al. (2005) reported a death due to cereulide consumption that caused hepatic failure.

Some strategies are useful in order to control these outbreaks, such as to prepare food in small portions to avoid long storage, maintenance of food on temperatures higher than $55^{\circ} \mathrm{C}$ and quick cooling of food on temperatures below $10^{\circ} \mathrm{C}$ (EHLING-SCHULZ et al., 2004). Furthermore, the adoption of programs such as Good Manufacturing Practices (GMP) and Hazard Analysis and Critical Control Points (HACCP) are useful to reduce the risks (KUMARI; SARKAR, 2016). Other strategies can be recommended, such as the use of autolysin (GENG et al., 2017), the addition of citric extract $\left(\mathrm{Citrox}^{\odot}\right)$ (TSIRAKI; SAVVAIDIS, 2016) or peptides (HAN et al., 2017), and the use of light emitting diode (LED) $(460 \mathrm{~nm})$ (KUMAR et al., 2017).

Although foodborne outbreaks caused by B. cereus sensu stricto (s.s.) are rarely caused through consumption of milk or dairy products (BENNETT et al., 2013), its presence is commonly described on them (KUMARI; SARKAR, 2016; VIDAL et al., 2016). The risk of foodborne illness because of its presence on these products is higher when they are obtained on illegal markets (YOBOUET et al., 2014). Furthermore, the production of diarrheic toxins is higher on psychrotrophic strains (EHLING-SCHULZ et al., 2004), which are more frequent in the dairy production chain (MCKILLIP, 2000).

B. cereus sensu stricto (s.s.) is important for dairy production chain not only due to its ability to cause foodborne illness, but also its spoilage potential and by reducing the shelf-life of dairy products because of proteases and lipases production (JONGHE et al., 2010; KUMARI; SARKAR, 2016). The presence of this bacteria is reported on several dairy products (WONG et al., 1988; VIDAL et al., 2016) and it occurs mainly due to the contamination of raw milk on farms and the heat-resistance of spores, including the capacity of survival to ultra-high temperature (UHT) process (VIDAL et al., 2016). Thus, hygienic practices during milk obtaining is essential to reduce the losses for this production chain. The $B$. cereus group was considered as the most prevalent and important foodborne bacteria on raw milk and on the environment of dairy farms (MCAULEY et al., 2014).

Moreover, the ability to form biofilms on stainless steel highlights the need of monitoring its occurrence and control through proper sanitation procedures on industries (KUMARI; SARKAR, 2016). HAYRAPETYAN et al. (2015) showed a higher capacity to form biofilm on stainless steel compared to polystyrene and justified it due to the quantity of free iron. Furthermore, the spores obtained from dry biofilms had lower heat-resistance when compared with those obtained from wet biofilms (HAYRAPETYAN et al., 2016).

The cleaning procedures adopted on dairy industries should be efficient to remove biofilm, but it is difficult due to the high resistance (SHAHEEN et al., 2010). Some researchers evaluated the efficacy of Clean in Place (CIP) used in dairy industries, which was considered inefficient to the total removal of biofilms (BREMER et al., 2006). Therefore, the discovery of new solutions should be encouraged (MAJED et al., 2016).

Still, some alternatives have been proposed, such as a new strategy to prevent biofilm adhesion using specific materials (PECHOOK et al., 2015), a heat-treatment combined with high-pressure treatment (SILVA, 2015), or also the use of gaseous chlorine dioxide (NAM et al., 2014; SILVA, 2015). 
It may be emphasized that the bacteria included in B. cereus group are an emerging danger to public health, as they are highly resistant and have genetic mechanisms for adapting on several factors and environment. Genomic studies that make effort to differentiate them are required in order to understand the real risk for public health or food industries due to contamination with distinct species. Likewise, other studies are essential to evaluate the genetic mechanisms involved and the factors that contribute to production of toxins and spoilage enzymes and biofilm formation, thinking about the development of new strategies to their control.

\section{ACKNOWLEDGEMENTS}

\author{
To São Paulo Research Foundation (FAPESP) (Grants
}

2014/13104-1, 2015/20874-0 and 2016/19214-9).

| | | | | | | | | | | | | | | | | | | | | | | | | | | | | | | | | | | | | | | | | | | | | | | | | | | | | | | | | | | | | | | | | | | | | | | | | | | | | | | | | | | | | | | | | | | | | | | | | | | | | | | | | | | | | | | | | | | | | | | | | | | | | | | | | | | | | | | | | | | | | | | | | | | | | | | | | | | | | | | | | | | | | | | | | | | | | | | | | | | | | | | | | | | | | | | | | | | | | | | | | | | | | | | | | | | | REFERENCES

BENNETT, S.D.; WALSH, K.A.; GOULD, L.H. Foodborne disease outbreaks caused by Bacillus cereus, Clostridium perfringens, and Staphylococcus aureus - United States, 1998-2008. Clinical Infectious Diseases, v.57, n.3, p. 425-433, 2013. Available from: <http://dx.doi.org/10.1093/cid/cit244>. Access on: 8 Dec. 2016. doi: $10.1093 / \mathrm{cid} /$ cit244

BREMER, P.J.; FILLERY, S.; MCQUILLAN, A.J. Laboratory scale clean-in-place (CIP) studies on the effectiveness of different caustic and acid wash steps on the removal of dairy biofilms. International Journal of Food Microbiology, v.106, n.3, p.254262, 2006. Available from: <http://dx.doi.org/10.1016/j. ijfoodmicro.2005.07.004>. Access on: 5 Dec. 2016. doi: 10.1016/j.ijfoodmicro.2005.07.004

CAAMAÑO-ANTELO, S.; FERNÁNDEZ-NO, I.C.; BÖHME, K.; EZZATALNAKIP, M.; QUINTELA-BALUJA, M.; BARROS-VELÁZQUEZ, J.; CALO-MATA, P. Genetic discrimination of foodborne pathogenic and spoilage Bacillus spp. based on three housekeeping genes. Food Microbiology, v.46, p.288-298, 2015. https://doi.org/10.1016/j. fm.2014.08.013

DIERICK, K.; VAN COILLIE, E.; SWIECICKA, I.; MEYFROIDT, G.; DEVLIEGER, H.; MEULEMANS, A.; HOEDEMAEKERS, G.; FOURIE, L.; HEYNDRICKX, M.; MAHILLON, J. Fatal family outbreak of Bacillus cereus-associated food poisoning. Journal of Clinical Microbiology, v.43, n.8, p.4277-4279, 2005. https://dx.doi. org/10.1 128\%2FJCM.43.8.4277-4279.2005

DOMMEL, M.K.; LÜCKING, G.; SCHERER, G.; EHLING-SCHULZ, M. Transcriptional kinetic analyses of cereulide synthetase genes with respect to growth, sporulation and emetic toxin production in Bacillus cereus. Food Microbiology, v.28, n.2, p.284-290, 2011. Available from: <http://dx.doi.org/10.1016/j.fm.2010.07.001>. Access on: 07 Nov. 2016. doi: 10.1016/j.fm.2010.07.001

EHLING-SCHULZ, M.; FRICKER, M.; SCHERER, S. Bacillus cereus, the causative agent of an emetic type of food-borne illness. Molecular Nutrition \& Food Research, v.48, p.479-487, 2004. Available from: <http://dx.doi.org/10.1002/mnfr.200400055>. Access on: 07 Nov. 2016. doi: 10.1002/mnfr.200400055

.; SVENSSON, B.; GUINEBRETIĖRE, M.H.; LINDBÄCK, T.; ANDERSSON, M.; SCHULZ, A.; FRICKER, M.; CHRISTIANSSON,
A.; GRANUM, P. E.; MÄRTLBAUER, E.; NGUYEN-THE, C.; SALKINOJA-SALONEN, M.; SCHERER, S. Emetic toxin formation of Bacillus cereus is restricted to a single evolutionary lineage of closely related strains. Microbiology, n.151, p.183197, 2005. Available from: <http://dx.doi.org/10.1099/ mic.0.27607-0>. Access on: 9 Oct. 2016. doi: 10.1099/ mic.0.27607-0.

FOOD AND DRUG ADMINISTRATION (FDA). The Bad Bug Book, Foodborne Pathogenic Microorganisms and Natural Toxins. Second Edition, 2012. Available from: <http://www.fda.gov/downloads/ Food/FoodbornelllnessContaminants/UCM297627.pdf>. Access on: 5 Dec. 2016.

GENG, P.; HU, Y.; ZHOU, G.; YUAN, Z.; HU, X. Characterization of three autolysins with activity against cereulide-producing Bacillus isolates in food matrices. International Journal of Food Microbiology, v.241, p.291-297, 2017. Available from: <http:// dx.doi.org/10.1016/j.ijfoodmicro.2016.10.030>. Access on: 1 Dec. 2016. doi: 10.1016/j.ijfoodmicro.2016.10.030

GUINEBRETIÈRE, M.-H.; AUGER, S.; GALLERON, N.; CONTZEN, M.; SARRAU B.; BUYSER, M.-L.; LAMBERET, G.; FAGERLUND, A.; GRANUM, P.E.; LERECLUS, D.; DE VOS, P.; NGUYEN-THE, C.; SOROKIN, A. Bacillus cytotoxicus sp. nov. is a novel thermotolerant species of the Bacillus cereus Group occasionally associated with food poisoning. International Journal of Systematic and Evolutionary Microbiology, n.63, p.31-40, 2013. Available from: <http://dx.doi.org/10.1099/ijs.0.030627-0>. Access on: 13 Nov. 2016. doi: 10.1099/ijs.0.030627-0

GOHAR, M.; FAEGRI, K.; PERCHAT, S.; RAVNUM, S.; ØKSTAD, O.A.; GOMINET, M.; KOLSTØ, A.-B.; LERECLUS, D. The PIcR Virulence Regulon of Bacillus cereus. PLOSONE, v.3, n.7, e2793, 2008. Available from: <http://dx.doi.org/10.1371/journal. pone.0002793>. Access on: 15 Dec. 2016. doi: 10.1371/ journal.pone.0002793

HAN, J.; GAO, P.; ZHAO, S.; BIE, X.; LU, Z.; ZHANG, C.; LV, F. iTRAQ-based proteomic analysis of LI-F type peptides produced by Paenibacillus polymyxa JSa-9 mode of action against Bacillus cereus. Journal of Proteomics, v. 150, p.130-140, 2017. Available from: <http://dx.doi.org/10.1016/j.jprot.2016.08.019>. Access on: 7 Dec. 2016 . doi: 10.1016/j.jprot.2016.08.019 
HAYRAPETYAN, H.; MULLER, L.; TEMPELAARS, M.; ABEE, T.; GROOT, M.N. Comparative analysis of biofilm formation by Bacillus cereus reference strains and undomesticated food isolates and the effect of free iron. International Journal of Food Microbiology, n.200, p.72-79, 2015. Available from: <http://dx.doi.org/10.1016/j. ijfoodmicro.2015.02.005>. Access on: 15 Dec. 2016. doi: 10.1016/j.ijfoodmicro.2015.02.005

; ABEE, T.; GROOT, M.N. Sporulation dynamics and spore heat resistance in wet and dry biofilms of Bacillus cereus. Food Control, v.60, p.493-499, 2016. Available from: <http://dx.doi. org/10.1016/j.foodcont.2015.08.027>. Access on: 20 Nov. 2016. doi: 10.1016/j.foodcont.2015.08.027

HELGASON, E.; ØKSTAD, O.A.; CAUGANT, D.A.; JOHANSEN, H.A.; FOUET, A.; MOCK, M.; HEGNA, I.; KOLSTØ, A.N. Bacillus anthracis, Bacillus cereus, and Bacillus thuringiensis-One Species on the Basis of Genetic Evidence. Applied and Environmental Microbiology, v.66, n.6, p.2627-2630, 2000. Available from: <http://dx.doi. org/10.1 128/AEM.66.6.2627-2630.2000>. Access on: 28 Oct. 2016. doi: 10.1128/AEM.66.6.2627-2630.2000

JEßBERGER, N.; KREY, V.M.; RADEMACHER, C.; BÖHM, M.-E.; MOHR, A.-K.; EHLING-SCHULZ, M.; SCHERER, S.; MÄRTLBAUER, E. From genome to toxicity: a combinatory approach highlights the complexity of enterotoxin production in Bacillus cereus. Frontiers in Microbiology, v.6, p.560, 2015. Available from: <http://dx.doi. org/10.3389/fmicb.2015.00560>. Access on: 14 Dec. 2016. doi: $10.3389 /$ fmicb.2015.00560

JIMÉNEZ, G.; URDIAIN, M.; CIFUENTES, A.; LÓPEZ-LÓPEZ, A.;

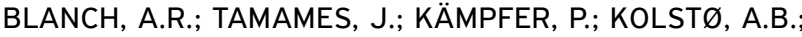
RAMÓN, D.; MARTÍNEZ, J.F.; CODOÑER, F.M.; ROSSELLÓ-MÓRA, R. Description of Bacillus toyonensis sp. nov., a novel species of the Bacillus cereus group, and pairwise genome comparisons of the species of the group by means of ANI calculations. Systematic and Applied Microbiology, v.36, n.6, p.383-391, 2013. Available from: <http://dx.doi.org/10.1016/j.syapm.2013.04.008>. Access on: 28 Nov. 2016. doi: 10.1016/j.syapm.2013.04.008

JONGHE, V.; COOREVITS, A.; BLOCK, J.; COILLIE, E.V.; GRIJSPEERDT, K.; HERMAN, L.; VOS, P.; HEYNDRICKX, M. Toxinogenic and spoilage potential of aerobic spore-formers isolated from raw milk. International Journal of Food Microbiology, v.136, n.3, p.318-325. Available from: <http://dx.doi.org/10.1016/j. ijfoodmicro.2009.11.007>. Access on: 28 Nov. 2016. doi: 10.1016/j.ijfoodmicro.2009.11.007

JUNG, M.-Y.; PAEK, W.K.; PARK, I.-S.; HAN, J.-R.; SIN, Y., PAEK, J., RHEE, M.-S.; KIM, H.; SONG, H.S.; CHANG, Y.-H. Bacillus gaemokensis sp. nov., isolated from foreshore tidal flat sediment from the Yellow Sea. The Journal of Microbiology, v.48, n.6, p.867-871, 2010. Available from: $<$ http://dx.doi.org/10.1007/s12275-010-0148O>. Access on: 28 Nov. 2016. doi: 10.1007/s12275-010-0148-0

.; KIM, J.-S.; PAEK, W.K.; LIM, J.; LEE, H.; KIM, P.I.; MA, J.Y.; KIM, W.; CHANG, Y.-H. Bacillus manliponensis sp. nov., a new member of the Bacillus cereus group isolated from foreshore tidal flat sediment. The Journal of Microbiology, v.49, n.6, p.1027-1032, 2011 . Available from: <http://dx.doi.org/10.1007/s12275-011-1049-6>. Access on: 15 Dec. 2016. doi: 10.1007/s12275-011-1049-6

KOVAC, J.; MILLER, R.A.; CARROLL, L.M.; KENT, D.J.; JIAN J.; BENO, S.M.; WIEDMANN, M. Production of hemolysin BL by Bacillus cereus group isolates of dairy origin is associated with whole-genome phylogenetic clade. BMC Genomics, v.17, n.581, 2016. Available from: <http://dx.doi.org/10.1186/s12864-016-2883-z>. Access on: 13 Nov. 2016. doi: 10.1186/s12864-016-2883-z.

KRANZLER, M.; STOLLEWERK, K.; ROUZEAU-SZYNALSKI, K.; BLAYO, L.; SULYOK, M.; EHLING-SCHULZ, M. Temperature exerts control of Bacillus cereus emetic toxin production on posttranscriptional levels. Frontiers in Microbiology, v.7, n. 1640, 2016. Available from: $<$ http://dx.doi.org/10.3389/fmicb.2016.01640>. Access on: 11 Dec. 2016. doi: 10.3389/fmicb.2016.01640

KUMAR, A.; GHATE, V.; KIM, M.-J.; ZHOU, W.; KHOO, G.H.; YUK, H.-G. Inactivation and changes in metabolic profile of selected foodborne bacteria by $460 \mathrm{~nm}$ LED illumination. Food Microbiology, v.63, p.12-21, 2017. Available from: <http://dx.doi.org/10.1016/j. fm.2016.10.032>. Access on: 17 Nov. 2016. doi: 10.1016/j. fm.2016.10.032

KUMARI, S.; SARKAR, P. Bacillus cereus hazard and control in industrial dairy processing environment. Food Control, v.69, p.20-29, 2016. Available from: <http://dx.doi.org/10.1016/j. foodcont.2016.04.012>. Access on: $07 \mathrm{Dec}$. 2016. doi: 10.1016/j.foodcont.2016.04.012

LINDBÄCK, T.; FAGERLUND, A;. RØDLAND, M.S.; GRANUM, P.E. Characterization of the Bacillus cereus Nhe enterotoxin. Microbiology, n. 150, p. 3959-3967, 2004. Available from: <http://dx.doi.org/10.1099/mic.0.27359-0>. Access on: 15 Dec. 2016. doi: 10.1099/mic.0.27359-0

LIU, B.; LIU, G.-H.; HU, G.-P.; CETIN, S.; LIN, N.-Q.; TANG, J.Y.; TANG, W.-Q.; LIN, Y.-Z. Bacillus bingmayongensis sp. nov., isolated from the pit soil of Emperor Qin's Terra-cotta warriors in China. Antonie van Leeuwenhoek, v.105, n.3, p.501-510, 2014. Available from: <http://dx.doi.org/10.1007/s10482-013-0102-3>. Access on: 01 Dec. 2016. doi: 10.1007/s10482-013-0102-3

LIU, Y.; LAI, Q.; GÖKER, M.; MEIER-KOLTHOFF, J.P.; WANG, M.; SUN, Y., WANG, L.; SHAO, Z. Genomic insights into the taxonomic status of the Bacillus cereus group. Scientific Reports, v.5, n. 14082 , 2015. Available from: <http://dx.doi.org/10.1038/srep 14082>. Access on: 15 Nov. 2016. doi: 10.1038/srep 14082

LÜCKING, G.; FRENZEL, E.; RÜTSCHLE, A.; MARXEN, S.; STARK, T.D.; HOFMANN, T.; SCHERER, S.; EHLING-SCHULZ, M. Ces locus embedded proteins control the non-ribosomal synthesis of the cereulide toxin in emetic Bacillus cereus on multiple levels. Frontiers in Microbiology, v.6, n.1001, 2015. Available from: <http:// dx.doi.org/10.3389/fmicb.2015.01101 >. Access on: 09 Dec. 2016. doi: $10.3389 /$ fmicb.2015.01101

MAJED, R.; FAILLE, C.; KALLASSY, M.; GOHAR, M. Bacillus cereus biofilms - same, only different. Frontiers in Microbiology, v.7, p. 1054, 2016. Available from: $<$ http://dx.doi.org/10.3389/fmicb.2016.01054>. Access on: 09 Dec. 2016. doi: 10.3389/fmicb.2016.01054

MARSTON, C.K.; IBRAHIM, H.; LEE, P.; CHURCHWELL, G.; GUMKE, M.; STANEK, D.; GEE, J.E.; BOYER, A.E.; GALLEGOS-CANDELA, M.; BARR, J.R.; LI, H.; BOULAY, D.; CRONIN, L.; QUINN, C.P.; HOFFMASTER, A.R. Anthrax toxin-expressing Bacillus cereus isolated from an anthraxlike eschar. Plos ONE, v. 1 1, n.6, e0156987, 2016. Available from: <http://dx.doi.org/10.1371/journal.pone.0156987>. Access on: 15 Dec. 2016. doi: 10.1371/journal.pone.0156987 
MARXEN, S.; STARK, T.D.; FRENZEL, E.; RÜSTCHLE, A.; LÜCKING, G.; PÜRSTINGER, G.; POHL, E.E.; SCHERER, S.; EHLING-SCHULZ, M.; HOFFMAN, T. Chemodiversity of cereulide, the emetic toxin of Bacillus cereus. Analytical and Bioanalytical Chemistry, v.407, n.9, p.2439-2453, 2015. Available from: <http://dx.doi. org/10.1007/s00216-015-8511-y>. Access on: 22 Nov. 2016. doi: $10.1007 / \mathrm{s} 00216-015-8511-y$

MAZZANTINI, D.; CELANDRONI, F.; SALVETTI, S.; GUEYE, S.A.; LUPETTI, A.; SENESI, S.; GHELARDI, E. FlhF is required for swarming motility and full pathogenicity of Bacillus cereus. Frontiers in Microbiology, v.7, p. 1644. Available from: <http:// dx.doi.org/10.3389/fmicb.2016.01644>. Access on: 15 Dec. 2016. doi: $10.3389 /$ fmicb.2016.01644

MCAULEY, C.M.; MCMILLAN, K.; MOORE, S.C.; FEGAN, N.; FOX, E.M. Prevalence and characterization of foodborne pathogens from Australian dairy farm environments. Journal of Dairy Science, v.97, n.12, p.7402-7412, 2014 . Available from: <http://dx.doi. org/10.3168/jds.2014-8735>. Access on: 07 Nov. 2016. doi: $10.3168 /$ jds.2014-8735

MCKILLIP, J.L. Prevalence and expression of enterotoxins in Bacillus cereus and other Bacillus spp., a literature review. Antonie van Leeuwenhoek, v.77, n.4, p.393-399, 2000. Available from: <http://dx.doi.org/10.1023/A:1002706906154>. Access on: 22 Nov. 2016. doi: 10.1023/A: 1002706906154

MILLER, R.A.; BENO, S.M.; KENT, D.J.; CARROLL, L.M; MARTIN, N.H.; BOOR, K.J.; KOVAC, J. Bacillus wiedmannii sp. nov. is a new psychrotolerant and cytotoxic Bacillus cereus group species isolated from dairy foods and environments in the USA. International Journal of Systematic and Evolutionary Microbiology, v.66, p.4744-4753, 2016. Available from: <http://dx.doi. org/10.1099/ijsem.0.001421 >. Access on: 15 Dec. 2016. doi: 10.1099/ijsem.0.001421

NAM, H.; SEO, H.-S.; BANG, J.; KIM, H.; BEUCHAT, L.R.; RYU, $\mathrm{J}$.-H. Efficacy of gaseous chlorine dioxide in inactivating Bacillus cereus spores attached to and in a biofilm on stainless steel. International Journal of Food Microbiology, v.188, p.122127, 2014. Available from: <http://dx.doi.org/10.1016/j. ijfoodmicro.2014.07.009>. Access on: 13 Nov. 2016. doi: 10.1016/j.ijfoodmicro.2014.07.009

OH, M.-H.; HAM, J.-S.; COX, J.M. Diversity and toxigenicity among members of the Bacillus cereus group. International Journal of Food Microbiology, v.152, n.1-2, p.1-8, 2012. Available from: <http://dx.doi.org/10.1016/j.jffoodmicro.201 1.09.018>. Access on: 04 Dec. 2016. doi: 10.1016/j.ijfoodmicro.2011.09.018

PATIÑO-NAVARRETE, R.; SANCHIS, V. Evolutionary processes and environmental factors underlying the genetic diversity and lifestyles of Bacillus cereus group bacteria. Research in Microbiology, v.168, n.4, p. 309-318, 2017. Available from: <http://dx.doi. org/10.1016/j.resmic.2016.07.002>. Access on: 13 Nov. 2016. doi: $10.1016 /$ j.resmic.2016.07.002

PECHOOK, S.; SUDAKOV, K.; POLISHCHUK, I.; OSTROV, I.; ZAKIN, V.; POKROY, B.; SHEMESH, M. Bioinspired passive anti-biofouling surfaces preventing biofilm formation. Journal of Materials Chemistry B, v.3, n.7, p.1371-1378, 2015. Available from: <http://dx.doi.org/10.1039/C4TBO1522C>. Access on: 15 Dec. 2016. doi: 10.1039/C4TBO1522C
SCARFF, J.M.; RAYNOR, M.J.; SELDINA, Y.I.; VENTURA, C.L.; KOEHLER, T.M.; O'BRIEN, A.D. The roles of AtxA orthologs in virulence of anthrax-like B. cereus G9241. Molecular Microbiology, v.102, n.4, p.545-561, 2016. Available from: <http://dx.doi. org/10.1111/mmi.13478>. Access on: 28 Nov. 2016. doi: $10.1111 / \mathrm{mmi} .13478$.

SCHAEFER, G.; CAMPBELL, W.; JENKS, J.; BEESLEY, C.; KATSIVAS, T.; HOFFMASTER, A.; MEHTA, S.R.; REED, S. Persistent Bacillus cereus bacteremia in 3 persons who inject drugs, San Diego, California, USA. Emerging Infectious Diseases, v.22, n.9, p. 1621, 2016. Available from: <https://dx.doi.org/10.3201/ eid2209.150647>. Access on: 01 Nov. 2016. doi: 10.3201/ eid2209.150647.

SCHLEIFER, K; WHITMAN, W.B. Bergey's manual of systematic bacteriology: The Firmicutes. $2^{\text {nd }}$ ed. New York: Springer, 2009.

SCHMID, D.; RADEMACHER, C.; KANITZ, E.E.; FRENZEL, E.; SIMONS, E.; ALLERBERGER, F.; EHLING-SCHULZ, M. Elucidation of enterotoxigenic Bacillus cereus outbreaks in Austria by complementary epidemiological and microbiological investigations, 2013. International Journal of Food Microbiology, v.232, p.8086, 2016. Available from: <https://dx.doi.org/10.1016/j. ijfoodmicro.2016.05.011 >. Access on: 09 Nov. 2016. doi: 10.1016/j.ijfoodmicro.2016.05.011

SHAHEEN, R.; SVENSSON, B.; ANDERSSON, M.A.; CHRISTIANSSON, A.; SALKINOJA-SALONEN, M. Persistence strategies of Bacillus cereus spores isolated from dairy silo tanks. Food Microbiology, v.27, n.3, p.347-355, 2010. Available from: <https://dx.doi.org/10.1016/j.fm.2009.11.004>. Access on: 13 Dec. 2016. doi: 10.1016/j.fm.2009.11.004

SILVA, F.V.M. High pressure processing of milk: Modeling the inactivation of psychrotrophic Bacillus cereus spores at $38-70^{\circ} \mathrm{C}$. Journal of Food Engineering, v. 165, p.141148, 2015. Available from: <http://dx.doi.org/10.1016/j. jfoodeng.2015.06.017>. Access on: 17 Nov. 2016. doi: 10.1016/j.jfoodeng.2015.06.017

THORSEN, L.; HANSEN, B.M.; NIELSEN, K.F.; HENDRIKSEN, N.B.; PHIPPS, R.K.; BUDDE, B.B. Characterization of emetic Bacillus weihenstephanensis, a new cereulide-producing bacterium. Applied and Environmental Microbiology, v.72, n.7, p.51185121, 2006. Available from: <http://dx.doi.org/10.1128/ AEM.00170-06>. Access on: 17 Nov. 2016. doi: 10.1128/ AEM.00170-06

TSILIA, V.; KERCKHOF, F.-M.; RAJKOVIC, A.; HEYNDRICKX, M.; WIELE, T.V. Bacillus cereus NVH 0500/00 can adhere to mucin but cannot produce enterotoxins during gastrointestinal simulation. Applied and Environmental Microbiology, v.82, n. 1, p.289-296, 2016. Available from: <http://dx.doi.org/10.1128/ AEM.02940-15>. Access on: 13 Dec. 2016. doi: 10.1128/ AEM.02940-15

TSIRAKI, M.I.; SAVVAIDIS, I.N. The effects of citrus extract (Citrox@) on the naturally occurring microflora and inoculated pathogens, Bacillus cereus and Salmonella enterica, in a model food system and the traditional Greek yogurt-based salad Tzatziki. Food Microbiology, v.53, part B, p.150-155, 2016. Available from: <http://dx.doi.org/10.1016/j.fm.2015.09.015>. Access on: 13 Dec. 2016. doi: 10.1016/j.fm.2015.09.015 
TUSGUL, S.; PROD'HOM, G.; SENN, L.; MEULI, R.; BOCHUD, P.-Y.; GIULIERI, B.S.G. Bacillus cereus bactaremia: A comparasion between haematological and non-haemotological patientes. New Microbes and New Infections, v. 15, p.65-71, 2017. Available from: <http://dx.doi.org/10.1016/j.nmni.2016.11.011 >. Access on: 15 Dec. 2016. doi: 10.1016/j.nmni.2016.11.011

VIDAL, A.M.C.; ROSSI JUNIOR, O.D.; ABREU, I. L.; BÜRGER, K.P.; VEDOVELLI, M.; GONÇALVES, A.C.S.; ROSSI, G.A.M.; D’ABREU, L.F. Detection of Bacillus cereus isolated during ultra high temperature milk production flowchart through random amplified polymorphic DNA polymerase chain reaction. Ciência Rural, v.46, n.2, p.286-292, 2016. Disponível em: <http://dx.doi. org/10.1590/0103-8478cr20141539>. Access on: 21 Nov. 2016. doi: 10.1590/0103-8478cr20141539

WARDA, A.K.; DEN BESTEN, H.M.W.; SHA, N.; ABEE, T.; GROOT, M.N.N. Influence of food matrix on outgrowth heterogeneity of heat damaged Bacillus cereus spores. International Journal of Food Microbiology, v. 201, p. 27-34, 2015. Available from: <http:// dx.doi.org/10.1016/j.ijfoodmicro.2015.02.010>. Access on: 15 Dec. 2016. doi: 10.1016/j.jffoodmicro.2015.02.010

.; TEMPELAARS, M.H.; BOEKHORST, J.; ABEE, T.; GROOT, M.N.N. Identification Identification of CdnL, a putative transcriptional regulator involved in repair and outgrowth of heatdamaged Bacillus cereus spores. Plos ONE, v. 1 1, n.2, e0148670, 2016. Available from: <http://dx.doi.org/10.1371/journal. pone.0148670>. Access on: 12 Dec. 2016. doi: 10.1371/ journal.pone.0148670

WONG, H.-C.; CHANG, M.-H.; FAN, J.-Y. Incidence and characterization of Bacillus cereus isolates contaminating dairy products. Applied Environmental Microbiology, v.54, n.3, p. 699-702, 1988.

YOBOUET, B.A.; KOUAMÉ-SINA, S.M.; DADIÉ, A.; MAKITA, K.; GRACE, D.; DJË, K. M.; BONFOH, B. Contamination of raw milk with Bacillus cereus from farm to retail in Abidjan, Côte d'Ivoire and possible health implications. Dairy Science \& Technology, v.94, n. 1, p.51-60, 2014. Available from: <http://dx.doi.org/10.1007/ s13594-013-0140-7>. Access on: 15 Dec. 2016. doi: 10.1007/ s13594-013-0140-7

ZHOU, G.; BESTER, K.; LIAO, B.; YANG, Z.; JIANG, R.; HENDRIKSEN, N.B. Characterization of three Bacillus cereus strains involved in a major outbreak of food poisoning after consumption of fermented black beans (douchi) in Yunan, China. Foodborne Pathogens $\odot$ Diseases, v. 1 1, n. 10, p.769-774, 2014. Available from: <http:// dx.doi.org/ 10.1089/fpd.2014.1768>. Access on: 15 Dec. 2016. doi: $10.1089 /$ fpd.2014.1768 